\title{
Prognostically relevant natural killer cell-mediated immunoediting in acute myeloid leukemia
}

\author{
Christopher J Chan ${ }^{1,2^{*}}$, Daniel M Andrews ${ }^{2,3}$, Mark J Smyth ${ }^{2,3,4}$, Paul J Neeson ${ }^{2,3}$, David S Ritchie ${ }^{2,3}$ \\ From Society for Immunotherapy of Cancer 28th Annual Meeting \\ National Harbor, MD, USA. 8-10 November 2013
}

Natural Killer (NK) cells contribute to the control of cancer through immunosurveillance and may influence phenotypic sculpting of cancer through immunoediting. NK cells may also contribute to the control of hematological malignancies such as acute myeloid leukemia (AML) following allogeneic stem cell transplantation. However, no studies have shown direct clinical evidence that supports immunoediting by NK cells in AML at presentation, or whether activating ligand expression at diagnosis serves as a prognostic indicator of survival. We now show that at diagnosis, expression of NK cell ligands on AML blast populations is heterogeneous. Furthermore, expression of multiple activating ligands is associated with favorable cytogenetics and improved leukemia-free survival. In analyses of paired diagnostic and relapse samples, AML blasts exhibiting lower expression of activating ligands were selectively increased at relapse, indicating that NK cellmediated blast immunoediting occurred prior to AML escape. Therapeutically, NK cell activating ligands could be upregulated on AML by in vitro treatment with bortezomib that enhanced NK cell-mediated cytotoxicity. Thus, diagnostic analyses of the expression of NK cell activating ligands in AML could be used to design therapeutic approaches for specific patients, and agents that stimulate NK cell function by restoring NK cell ligand expression may be appropriate to eliminate minimal residual disease and reduce risk of relapse.

\section{Authors' details}

${ }^{1}$ Immunology, Monash University, Melbourne, VIC, Australia. ${ }^{2}$ Cancer Immunology, Peter MacCallum Cancer Centre, Melbourne, VIC, Australia. ${ }^{3}$ Sir Peter MacCallum Department of Oncology, University of Melbourne, Melbourne, VIC, Australia. ${ }^{4}$ Medicine, University of Queensland, Herston, QLD, Australia.

${ }^{1}$ Immunology, Monash University, Melbourne, VIC, Australia

Full list of author information is available at the end of the article
Published: 7 November 2013

doi:10.1186/2051-1426-1-S1-P181

Cite this article as: Chan et al:: Prognostically relevant natural killer cellmediated immunoediting in acute myeloid leukemia. Journal for ImmunoTherapy of Cancer 2013 1(Suppl 1):P181.
Submit your next manuscript to BioMed Central and take full advantage of:

- Convenient online submission

- Thorough peer review

- No space constraints or color figure charges

- Immediate publication on acceptance

- Inclusion in PubMed, CAS, Scopus and Google Scholar

- Research which is freely available for redistribution
C Biomed Central 